\title{
Spatial Distribution of Rainfall Variability and Trend Analysis of Damoh District of Madhya Pradesh
}

\author{
Rajesh Khavse $^{1 *}$, Anup Badgaiya ${ }^{1}$, A. K. Shrivastava ${ }^{1}$ and T. R. Sharma ${ }^{2}$ \\ ${ }^{1}$ Krishi Vigyan Kendra, Damoh. JNKVV, Jabalpur, Madhya Pradesh, India \\ ${ }^{2} D E S$, JNKVV, Jabalpur, India \\ *Corresponding author
}

\section{A B S T R A C T}

Keywords

Rainfall, Monthly,

Seasonal and

Annual and

Variability

Article Info

Accepted:

18 December 2020

Available Online:

10 January 2021
Rainfall variability is one of the key factors that affect agricultural production in any region. Hence the proper understanding of rainfall pattern and its trend may help water resources development and to take decision for the developmental activities of that place. The present study is on attempt to evaluate the temporal variability of Damoh district of Madhya Pradesh, India, during the period from 1901 to 2019. Long term change in rainfall was determined by Mann-Kendall rank statistics and linear trend analysis. The analysis revealed insignificant slight decrease in all monsoon rainfall season over Damoh district of Madhya Pradesh. Rainfall decline is more predominant in June, July, August but not so in September during the monsoon season. An important aspect of the present study is the insignificant increase in all season. There was a major shift in rainfall pattern temporarily during recent years as indicates that the decades wise increasing in annual and postmonsoon rainfall is significant at 0.01 and 0.05 levels respectively. It is also pre-monsoon, south west monsoon and winter rainfall of Damoh district of Madhya Pradesh shows increasing trend.

\section{Introduction}

The term monsoon seems to have been derived either from the Arabic mausim or from the Malayan monsin. As first used it was applied to southern Asia and the adjacent waters, where it referred to the seasonal surface air streams which reverse their directions between winter and summer, southwest in summer and north east in winter in this area. During the summer the continent is heated, leading to rising motion and lower pressure. This induces airflow from sea to land at low elevations.
India is basically an agricultural country and the success or failure of the harvest and water scarcity in any year is always considered with the greatest concern. Several researchers studied on variability and trends in rainfall across the world. Nicholson (2000) observed that one of the most important contrasts in rainfall is the multi-decadal persistence of anomalies over northern Africa. Nicholson and Grist (2001) had identified several changes in the general atmospheric circulation that have accompanied the shift to drier conditions in West African Sahel. 
Rainfall variability in southern Spain on decadal to centennial time scales were studied by Rodrigo et al., (2000). Rotstayn and Lohmann (2002) showed a prominent feature in the drying of the Sahel in North Africa and suggest that the indirect effects of anthropogenic sulfate may have contributed to the Sahelian drying trend. Akinremi et al., (2001) reported that there has been a significant increase in rainfall and its events during the most recent 40-year period (195695). Increase in annual rainfall was $51 \mathrm{~mm}$, or about $16 \%$ of the 40 -year mean, while the number of rainfall events increased by 17 , or about $29 \%$ on the Canadian prairies. Murphy and Timbal (2007) reported that most of the rainfall decline (61\%) has occurred in Autumn (March-May) in southeastern Australia. A similar rainfall decline occurred in the southwest of Western Australia around 1970 that has many common features with the southeastern Australia decline. Guhathakurta and Rajeevan (2007) observed decreasing trend in almost all subdivisions except for subdivisions in Himachal Pradesh, Jharkhand and Nagaland, Manipur, Mizoram and Tripura during winter.

\section{Materials and Methods}

\section{Study Area}

Damoh district of Madhya Pradesh state is located between $23^{\circ}$ 50'20.59" North and $79^{\circ} 26^{\prime}$ 27.69" East. The average annual rainfall of Damoh district is $1195.0 \mathrm{~mm}$. Damoh district received maximum rainfall during southwest monsoon period i.e. June to September. About $90.7 \%$ of the annual rainfall received during monsoon season. Only $9.6 \%$ of the annual rainfall takes place between October to May period. Thus, surplus water for ground water recharge is available only during the southwest monsoon period. The normal maximum temperature received during the month of May is $42.0^{\circ} \mathrm{C}$ and minimum during the month of December/January is $9.7^{\circ} \mathrm{C}$. The normal annual means maximum and minimum temperatures of Damoh district is $32.6^{\circ}$ and $18.9^{\circ} \mathrm{C}$ respectively (Table 1 ). During the southwest monsoon season the relative humidity generally exceeds $88 \%$ (August month). In the rest of the year it is drier. The driest part of the year is the summer season, when relative humidity is less than $31 \%$. May is the driest month of the year. It is at an average elevation of 595 meters $(1,952 \mathrm{ft})$. The district of Damoh has an area of 7,306 square $\mathrm{km}(2,821 \mathrm{sq} \mathrm{mi})$.

From the basic monthly rainfall data, monthly mean, seasonal rainfall, standard deviation (SD) and coefficient of variation (C.V.) were computed monthly and season-wise viz., Premonsoon (March-May), Southwest monsoon (June-September), Post-monsoon (OctoberDecember) and Winter (January -February) that are depicted in Table 2. The data were subjected to 30-year-running mean to find out long term trends. A linear trend line was added to the series for simplify the trends. To support trends in annual and seasonal rainfall, over Damoh district of Madhya Pradesh were also analyzed from the period 1901 to 2019. Temporal changes in the seasonal and annual rainfall were also analyzed by Man-Kendall rank statistics (t) to confirm the significance of the observed trend. The values of $t$ were used as the basis of a significance test by comparing it with

$$
T_{t}=0 \pm I_{g} \sqrt{4 N+10 / 9 N(N-1)}
$$

Where $\operatorname{tg}$ is the desired probability point of the Gaussian normal distribution. In the present study, tg at 0.01 and 0.05 points were considered for comparison. Apart from this, the linear trend fitted to the data was also tested with $t$ test to verify results obtained by Mann-Kendall test. 


\section{Rainfall features}

Rainfall characteristics of Damoh district are reported in Table 2. The annual normal rainfall over Damoh district from 1901 to 2019 is 1195.8 with a standard deviation of $256.8 \mathrm{~mm}$. The coefficient of variation of annual rainfall is $21.5 \%$, indicating that it is stable. Rainfall during August is the highest $(389.4 \mathrm{~mm})$ which contributes to $32.3 \%$ of annual rainfall, followed by July $366.5 \mathrm{~mm}$ contributes (40.3\%). Rainfall in June and September contributes to $22.6 \%$ and $21.5 \%$ of the annual rainfall respectively.

Rainfall in January is the least $(17.0 \mathrm{~mm})$ and contributes only $1.4 \%$ to the annual rainfall. The coefficient of variation is also the highest during November (178.7\%) followed by December (166.8\%), April (137.1\%), whereas other months like March (121.9\%), February $(118.4 \%)$ and shows comparably higher CV. The coefficient of variation was least during the high rainfall months of July (40.3\%) and August (32.3\%). Rainfall during the southwest monsoon (June-September) contributes $90.7 \%$ of the annual rainfall. The contribution of pre monsoon (March-May), post-monsoon and winter rainfall to the annual is $1.9 \%, 4.5 \%$ and $2.8 \%$ respectively.

The seasonal rainfall during monsoon (JuneSept.) is dependable as the coefficient of variation is $22.6 \%$. At the same time, rainfall during post monsoon is undependable if coefficient of variation is high (85.7\%).

\section{Results and Discussion}

\section{Annual rainfall Trend}

The mean annual rainfall of Damoh district of Madhya Pradesh showed a long term insignificant declining trend. However, the decreasing trend in annual rainfall was no significant if the annual rainfall considered from 1901 onwards.

\section{Seasonal rainfall Trends}

Pre-monsoon: The increasing trend was noticed up to 1901-1930 in first decade while decreasing trend from 1931-2019 (Fig.2). There was insignificant decreasing trend during the study period of 1901-2019 years.

South-West monsoon: The southwest monsoon rainfall was more from 1901 to 1930 against the normal while decreasing trend from 1931to 1990 and again increasing trend in fourth decade (Fig.2). The MannKendall test statistics (-0.429) indicates that the decrease in southwest monsoon rainfall is insignificant at 0.01 and 0.05 levels.

Post-monsoon: Post-monsoon rainfall depicts of high rainfall in two decade from 1910-1960 against the normal while decreasing trend from 1961 to 2019 (Fig.2). The MannKendall test indicated that the seasonal rainfall during the post-monsoon is showing decreasing trend which is significant at 0.05 level. Therefore, it can be inferred that the post-monsoon rainfall was significantly decreasing. Such trend was more evident since 1970 onwards.

Winter monsoon: The winter rainfall was decreasing trend from1901-2019, which is not statistically significant. The decade wise winter rainfall slightly increased from 1901 to 1990 (Fig.2). The decreasing trend in last two decade. However, high variability of rainfall lead to uncertainty and the crops need assured irrigation.

Monthly rainfall trends: Behavior of monthly rainfall has been studied for individual months by subjecting them to the Mann-Kendall test. The results are presented in Table 4. It is interesting to note that rainfall in November showed significant decreasing trend at 0.01 level. Rainfall of June month showed an insignificant increasing trend. 
Rainfall during January, February, March, April, May, July August, September and December showed insignificant decreasing trend.

There was increasing trend in (9-13\%) rainfall contribution of June to the annual rainfall over a period of time (Table 5). The contribution of rainfall during July is stable though variations were noticed from one-and three decades. In contrast, the contribution of rainfall during August (27.4-36.1\%) and September $(14.0-18.0 \%)$ is decreasing.
Similar decreasing trends were noticed during October and November in rainfall contribution to the annual. As a whole, the percentage rainfall contribution during the southwest monsoon was declining while decreasing during pre- and post-monsoon season and winter rainfall of Damoh district of Madhya Pradesh. However, rainfall during the monsoon season is stable while instable in remaining months. These two contrasting phenomena in seasonal rainfall trends are the major concern across the Damoh district of Madhya Pradesh.

Table.1 Normal Climatologically Parameters for Damoh district

\begin{tabular}{|l|l|l|l|l|l|l|l|l|l|l|l|l|l|l|}
\hline S.No. & Parameters & Jan & Feb. & March & April & May & June & July & Aug. & Sept. & Oct. & Nov. & $\begin{array}{l}\text { Dec } \\
\text { Annu }\end{array}$ & $\begin{array}{l}\text { Anl } \\
\text { al }\end{array}$ \\
\hline $\mathbf{1}$ & Maximum temp. & 26.2 & 29.4 & 34.5 & 39.3 & 42.0 & 38.0 & 31.1 & 29.8 & 31.4 & 32.3 & 29.9 & 26.7 & 32.6 \\
\hline $\mathbf{2}$ & Minimum temp. & 9.7 & 12.1 & 16.6 & 21.9 & 26.4 & 26.6 & 24.2 & 23.7 & 23.3 & 19.2 & 13.1 & 9.7 & 18.9 \\
\hline $\mathbf{3}$ & $\begin{array}{l}\text { Relative humidity } \\
(\%)\end{array}$ & 69 & 58 & 43 & 33 & 31 & 59 & 85 & 88 & 82 & 70 & 65 & 70 & 63 \\
\hline $\mathbf{4}$ & $\begin{array}{l}\text { Wind speed } \\
(\mathrm{km} / \mathrm{hr})\end{array}$ & 3.2 & 3.7 & 4.3 & 5.0 & 6.3 & 8.2 & 7.2 & 6.9 & 5.4 & 3.5 & 2.7 & 2.6 & 4.9 \\
\hline
\end{tabular}

Table.2 Monthly and seasonal means of rainfall (mm) over Damoh district 1901-2019

\begin{tabular}{|l|c|c|c|c|c|}
\hline \multirow{2}{*}{ Months/ Seasons } & \multicolumn{4}{|c|}{ Rainfall (mm) } \\
\cline { 2 - 5 } & Normal & S.D & C.V \% & $($ \%) contribution to Annual Rainfall \\
\hline Jan. & 17.0 & 19.6 & 115.6 & 1.4 \\
\hline Feb. & 16.4 & 19.4 & 118.4 & 1.4 \\
\hline March & 11.4 & 13.9 & 121.9 & 1.0 \\
\hline April & 5.6 & 7.7 & 137.1 & 0.5 \\
\hline May & 6.3 & 6.9 & 109.5 & 0.5 \\
\hline June. & 140.2 & 101.1 & 72.1 & 11.7 \\
\hline July & 366.5 & 147.7 & 40.3 & 30.7 \\
\hline August & 389.4 & 125.8 & 32.3 & 32.6 \\
\hline Sept. & 188.8 & 99.8 & 52.9 & 15.8 \\
\hline Oct. & 29.8 & 34.7 & 116.5 & 2.5 \\
\hline Nov. & 14.8 & 26.4 & 178.7 & 1.2 \\
\hline Dec. & 9.6 & 16.0 & 166.8 & 0.8 \\
\hline Annual & 1195.8 & 256.8 & 21.5 & 100.0 \\
\hline Pm (March-May) & 23.3 & 18.7 & 80.2 & 1.9 \\
\hline SW (June- Sept.) & 1084.9 & 245.7 & 22.6 & 90.7 \\
\hline Post M (Oct-Dec) & 54.2 & 46.5 & 85.7 & 4.5 \\
\hline Winter (Jan-Feb) & 33.3 & 27.8 & 234.1 & 2.8 \\
\hline
\end{tabular}


Table.3 Linear Equation and their significant tested by T-test

\begin{tabular}{|c|c|c|}
\hline Month & Linear equation & Calculated T-values \\
\hline Annual rainfall $(\mathbf{m m})$ & $\mathrm{Y}=-0.501 \mathrm{x}+1225$ & 1.364 \\
\hline Pre- monsoon & $\mathrm{Y}=-0.054 \mathrm{x}+26.57$ & 0.890 \\
\hline S-W monsoon & $\mathrm{Y}=-0.254 \mathrm{x}+1100$ & 1.145 \\
\hline Post- monsoon & $\mathrm{Y}=-0.150 \mathrm{x}+63.26$ & 0.695 \\
\hline Winter & $\mathrm{Y}=0.041 \mathrm{x}+35.83$ & 0.713 \\
\hline
\end{tabular}

*significant at $0.05 \%, * *$ significant at $0.01 \%$ level

Table.4 Mann- Kendall Rank Statistics of monthly and seasonal Rainfall over Damoh district of Madhya Pradesh

\begin{tabular}{|c|c|}
\hline Month & Mann- Kendall Rank Statistics \\
\hline Jan & -1.054 \\
\hline Feb & -1.635 \\
\hline Mar & -1445 \\
\hline Apr & -1383 \\
\hline May & -0.992 \\
\hline Jun & 0.618 \\
\hline Jul & -1.059 \\
\hline Aug & -0.783 \\
\hline Sep & -1.681 \\
\hline Oct & -0.825 \\
\hline Nov & $-3.294 *$ \\
\hline Dec & -1.298 \\
\hline Annual rainfall(mm) & -0.836 \\
\hline Pre- monsoon & -1.369 \\
\hline South west monsoon & -0.429 \\
\hline Post monsoon & -1.762 \\
\hline Winter & -1.192 \\
\hline *significant at 0.05\%, ** significant at 0.01\% level \\
\hline
\end{tabular}

Table.5 Monthly and seasonal contribution of rainfall (\%) to annual from 1901 to 2019 over Damoh district of Madhya Pradesh

\begin{tabular}{|l|c|c|c|c|}
\hline Year & $\mathbf{1 9 0 1 - 1 9 3 0}$ & $\mathbf{1 9 3 1 - 1 9 6 0}$ & $\mathbf{1 9 6 1 - 1 9 9 0}$ & $\mathbf{1 9 9 1 - 2 0 1 9}$ \\
\hline June. & 9.6 & 12.3 & 12.0 & 13.1 \\
\hline July & 30.2 & 34.2 & 27.3 & 30.9 \\
\hline August & 31.2 & 35.4 & 36.1 & 27.4 \\
\hline Sept. & 15.5 & 18.0 & 15.7 & 14.0 \\
\hline Oct. & 2.2 & 3.4 & 2.6 & 1.8 \\
\hline Nov. & 1.5 & 1.2 & 1.3 & 0.9 \\
\hline PM (March-May) & 2.1 & 2.0 & 1.8 & 1.8 \\
\hline SW (June- Sept.) & 86.4 & 99.9 & 91.1 & 85.3 \\
\hline Post M (Oct-Dec.) & 4.6 & 5.1 & 5.1 & 3.3 \\
\hline Winter (Jan-Feb.) & 2.6 & 3.3 & 2.9 & 2.3 \\
\hline
\end{tabular}


Fig.1 Annual Rainfall Trend of Damoh district of Madhya Pradesh from 1901-2019
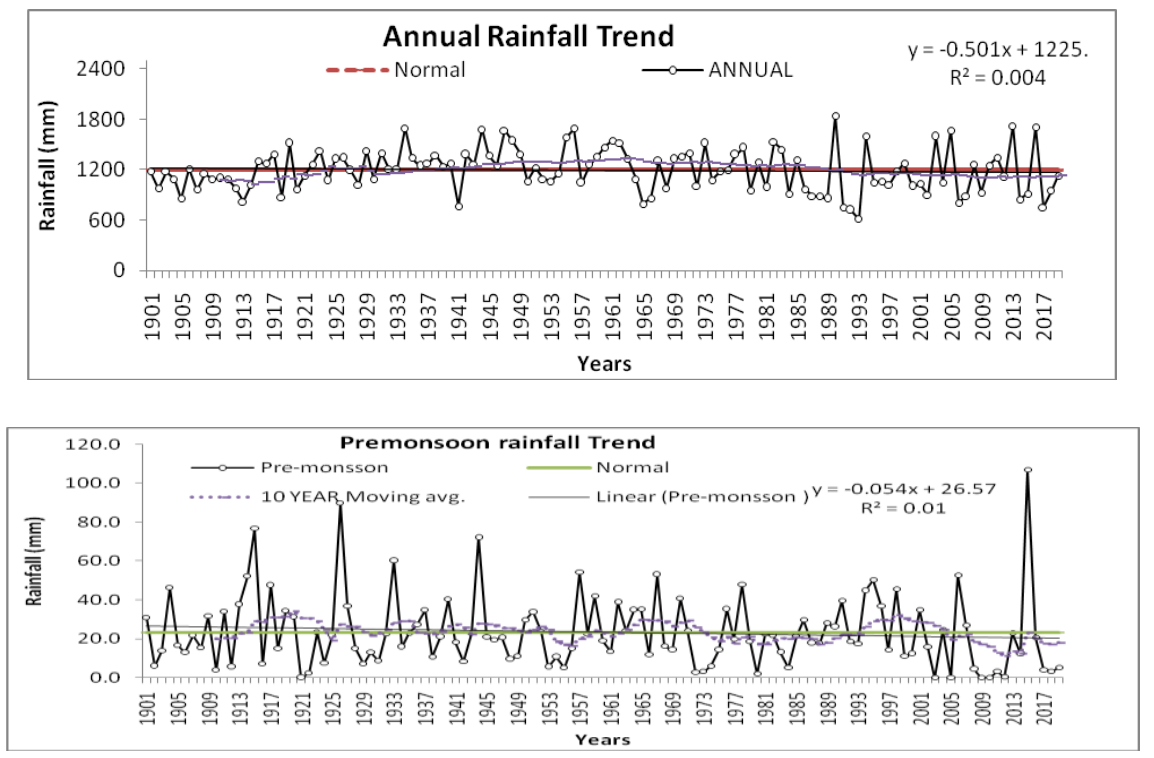

Fig.2 Seasonal Rainfall (Pre-monsoon, South West, Post- monsoon and winter) of Damoh district of Madhya Pradesh from 1901-2019
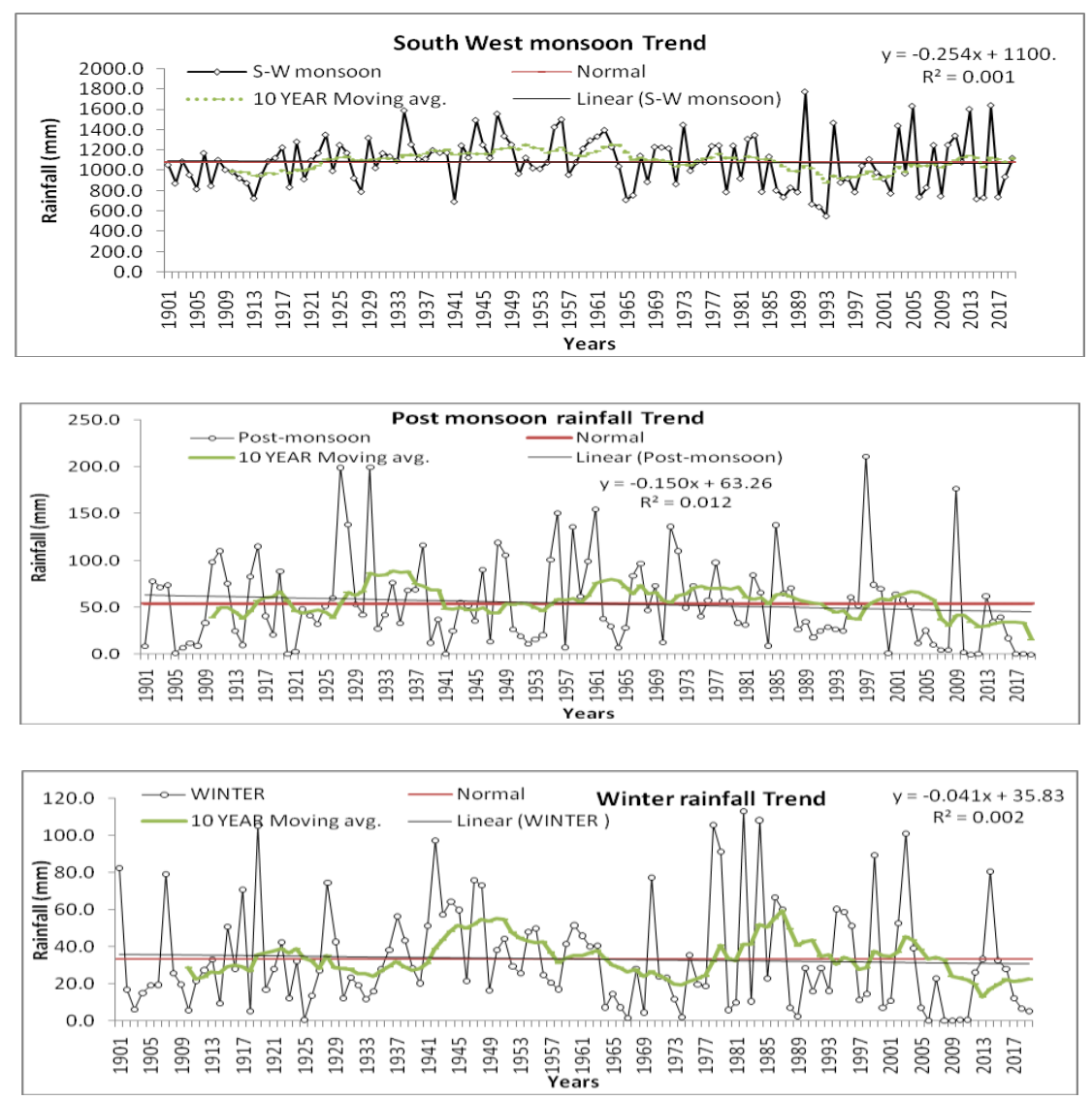
In conclusion an important aspect of the present study is the insignificant slight decrease in all monsoon rainfall season over Damoh district of Madhya Pradesh. The coefficient of variation was least during the high rainfall months of July $(40.3 \%)$ and August (32.3\%). Rainfall during the southwest monsoon (June-September) contributes $90.7 \%$ of the annual rainfall. The contribution of pre monsoon (March-May), post-monsoon and winter rainfall to the annual is $1.9 \%, 4.5 \%$ and $2.8 \%$ respectively. The seasonal rainfall during monsoon (JuneSept.) is dependable as the coefficient of variation is $22.6 \%$. At the same time, rainfall during post monsoon is undependable if coefficient of variation is high $(85.7 \%)$. Rainfall decline is more predominant in June, July, August but not so in September during the monsoon season. There was a major shift in rainfall pattern temporarily during recent years as seasonal rainfall during the southwest monsoon were increasing and also increasing pre-monsoon, post-monsoon and winter season.

\section{Acknowledgement}

The present work was carried out under ICAR, Network Project on District Agromet Units (DAMUs) funded by Indian Council of Agriculture Research, New Delhi, and also I would like to thank the Senior Scientist and Head for providing the necessary facilities for the conducting work.

\section{References}

Akinremi, O.O., Mcginn, S.M., Cutforth, H.W. (2001): Seasonal and spatial patterns of rainfall trends on the Canadian Prairies, Journal of Climate., 14 (9): 2177-2182.

Guhathakurta, P., Rajeevan, M., (20070: Trend in the rainfall pattern over India, International Journal of Climatology.,
28(11):1453-1469

Joseph, P.V., Simon, A, Nair, Venu G., Thomas, A. (2004): Intra-Seasonal Oscillation (ISO) of south Kerala rainfall during the summer monsoons of 1901-1995. In: Proceedings of the Indian Academy of Sciences Earth Planetary Sciences., 113(2):139-150.

Joseph, P.V., Simon, A. (2005): Weakening trend of the southwest monsoon current through peninsular India from 1980 to the present. Current Science., 89:687694.

Krishnakumar, K.N., G.S.L.H.V. Prasada Rao, Gopakumar, C.S. (2009): Rainfall trends in twentieth century over Kerala, India, Atmospheric Environment., 43:1940-1944.

Murphy, B. F., Timbal, B. (2007): A review of recent climate variability and climate change in southeastern Australia, International Journal of Climatology., 10:1002-1627

Nicholson, S. E., (2000): The nature of rainfall variability over Africa on time scales of decades to millennia, Global and Planetary Change., 26 (1-3):137158.

Nicholson, S.E., Grist, J.P. (2001): A conceptual model for understanding rainfall variability in the West African Sahel on inter-annual and inter-decadal timescales, International Journal of Climatology., 21 (14):1733-1757.

Parthasarathy, B., Dhar, O.N. (1978): Climate Fluctuations Over Indian RegionRainfall, Indian Institute of Tropical Meteorology Pune., 31:025.

Pant, G.B., Rupa Kumar, K. (1997): Climate of South Asia, john Wiley and sons, Chichester., 38

Rajendra K. J., Dash, S.K. (2001): Inter decadal variations of characteristics of monsoon disturbances and their epochal relationships with rainfall and other tropical features, International Journal 
of Climatology., 21 (6):759-771.

Rao, B.R.S., Rao, D.V.B., Rao, V.B. (2004):

Decreasing trend in the strength of Tropical Easterly Jet during the Asian summer monsoon and the number of tropical cyclonic system over Bay of Bengal, Geophysics Research Letter., 31(10):1029.

Radirigo, S., Esteban-perra, M.J., PozoVazquez, D., Castro-Diez, Y., (2000):
Rainfall variability in southern spain on decadal to centennial time scale, international journal of climatology., 20(7):721-732.

Rotstayn, L. D., Lohmann, U. (2002): Tropical rainfall trends and the indirect aerosol effect, Journal of Climate., 15:2103-2116.

\section{How to cite this article:}

Rajesh Khavse, Anup Badgaiya, A. K. Shrivastava and Sharma, T. R. 2021. Spatial Distribution of Rainfall Variability and Trend Analysis of Damoh District of Madhya Pradesh. Int.J.Curr.Microbiol.App.Sci. 10(01): 2718-2725.

doi: https://doi.org/10.20546/ijcmas.2021.1001.316 